\title{
Proposal of Use of Welded Joints EN AW-6082 for Adapters of Forest Technic
}

\author{
Miroslava Ťavodová ${ }^{1}$, Michaela Hnilicová1, Tomáš Švantner ${ }^{2}$ \\ ${ }^{1}$ Faculty of Environmental and Manufacturing Technology, Technical University in Zvolen, Študentská 26, 960 53. Slo- \\ vak Republic, tavodova@tuzvo.sk, michaela.hnilicova@tuzvo.sk \\ ${ }^{2}$ Department of Materials and Mechanics of Machines SAS, detached workplace Žiar nad Hronom, Priemyselná 12, 965 \\ 01 Ladomerská Vieska, Slovak Republic, tomas.svantner@savba.sk
}

Forestry is characterized by a diversity of natural conditions, which need to be adapted not only to the selection and application of technological processes, but also to the materials used in the construction of individual parts of the equipment. The article deals with the possibility of replacing steel elements with aluminium ones for selected parts of the adapter frame designed for liquidation of forest fires. The aim is to achieve a gradual reduction in its total weight. The aluminium sheet AISiMgMn EN AW-6082 was selected a replacement for the steel parts. The filler material was solid wire AIMg5Cr. Welding was performed by the MIG method. The selected welding parameters should guarantee the creation of a quality joint that can replace steel weld joints, while respecting the demands placed on them. Weld joints were analysed by macroscopic analysis, measurement of hardness by HV1 and SEM analysis of welded joint with EDX analysis. The results of the laboratory experiment show that by the chosen welding procedure with given parameters, quality welded joints were achieved. After further analyses, these weld joints can be recommended as a substitute for the previously used weld joints of steel structures.

Keywords: welded joint, AlSiMgMn, hardness, microstructure, adapter of forest technic

\section{Introduction}

Forest production includes a very wide range of production technologies and workflows where progressive technical means can be used in present [1]. The basic mechanisms working in forestry education and cultivation activities includes iron horses, balancing equipment, adapters and dedicated devices based on chainsaws, tree transplanting mechanisms, very light forest cable cars, light forest cable cars and tractor technologies. Research and development of technical solutions will achieve the desired result if the technical solutions respect natural, technological, economic and ergonomic requirements [2]. From this perspective, it is also necessary to focus on the total weight of forest mechanisms. They work in an environment often suffering from a high load, which contributes to the devastation of the work environment. We can contribute to reducing this unfavourable condition by using lighter structures for their construction. One of the way to lighten the construction is to use lighter materials such as eg, aluminium alloys. Forest mechanisms consist of many construction nodes including weld joints. The strength of these joints shall be sufficient to withstand different types of loads and stresses and be comparable to steel weld joints.

\section{Materials and methods}

Safety design is not only about designing and dimensioning of machinery, but also about creating a complete system meeting the defined objectives. Therefore, when designing adapters that are used as forestry equipment attachments, it is necessary to approach from two perspectives. The first is the purpose for which the adapters are designed (operating characteristics) and the second is the effect on the operator or other employees working in the immediate vicinity. The role of design engineers dealing with technical (operational) parameters to ensure the highest efficiency of the machine with the adapter. The role of safety engineers is to minimize hazards arising throughout the life of the machinery $[2,3]$.

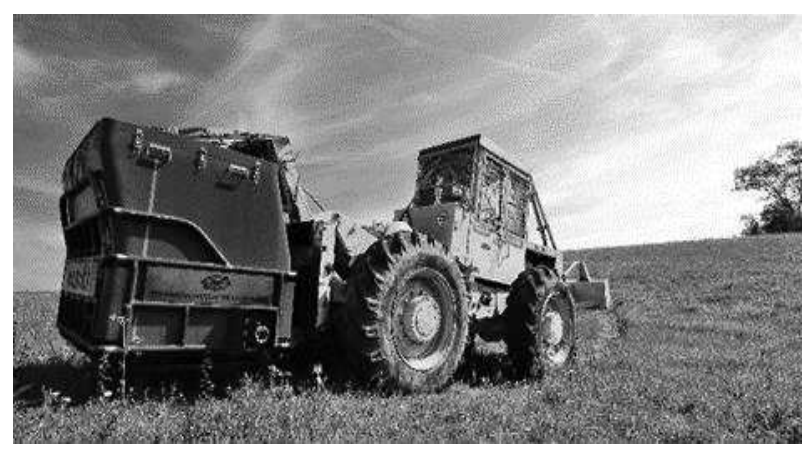

Fig. 1 Base machine with adapter [4]

Adapter - firefighting superstructure, as an additional equipment of a forest wheeled tractor (or another suitable base machine) is primary designed for liquidation of forest fires in inaccessible terrains (Figure 1 and Figure 2b).

Furthermore, it can be used for emergency import of material in inaccessible terrain. In this case, a composite water tank is removed from the protective steel frame (Figure 2a). The water tank can be refilled with a Bambi bag using a helicopter. The adapter can be used as a replacement of closed pond systems (bags, type II, used in the past from the reserves of the Armed Force of the Slovak Republic) [4,5].

In additional to this, the fire adapter can also be used to provide water transport for nurseries (irrigation), areas in case of prolonged drought, replenishment of watering place for forest animals and filling of puddles during the dry season. 

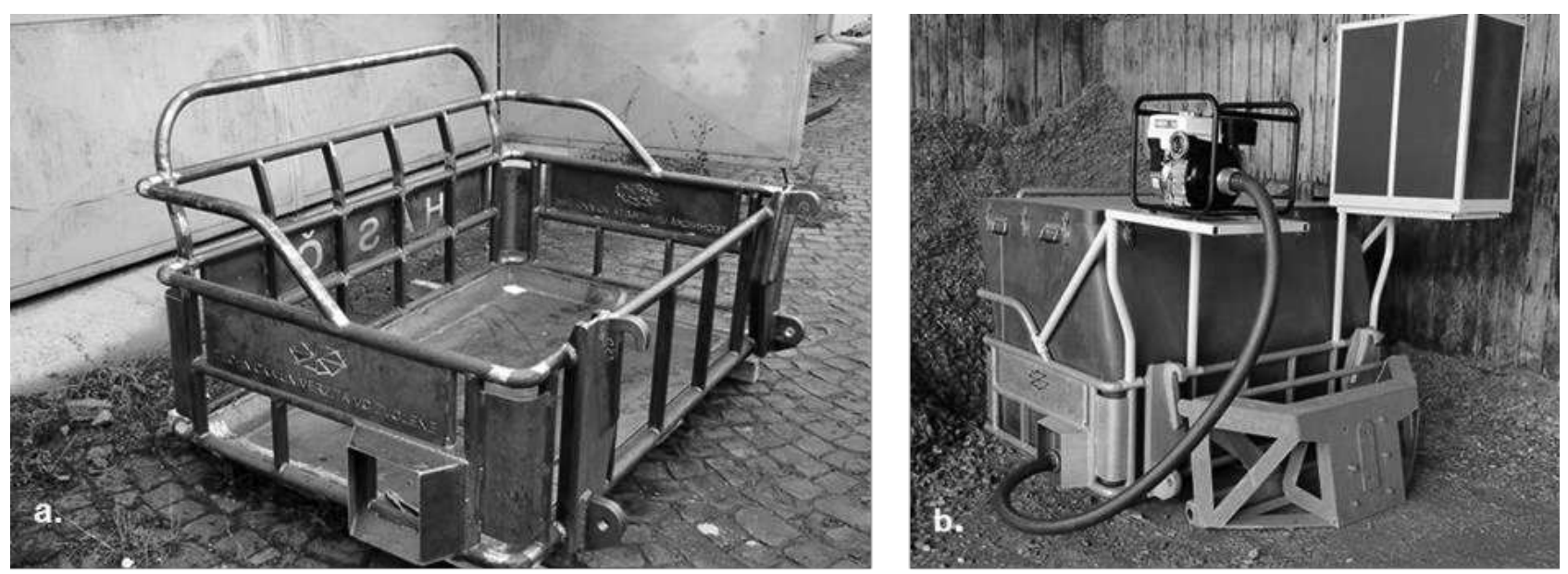

Fig. 2 Firefighting adapter DATEFF adapter frame (a.), adapter with forest fire fighting accessories (b.) [4,5]

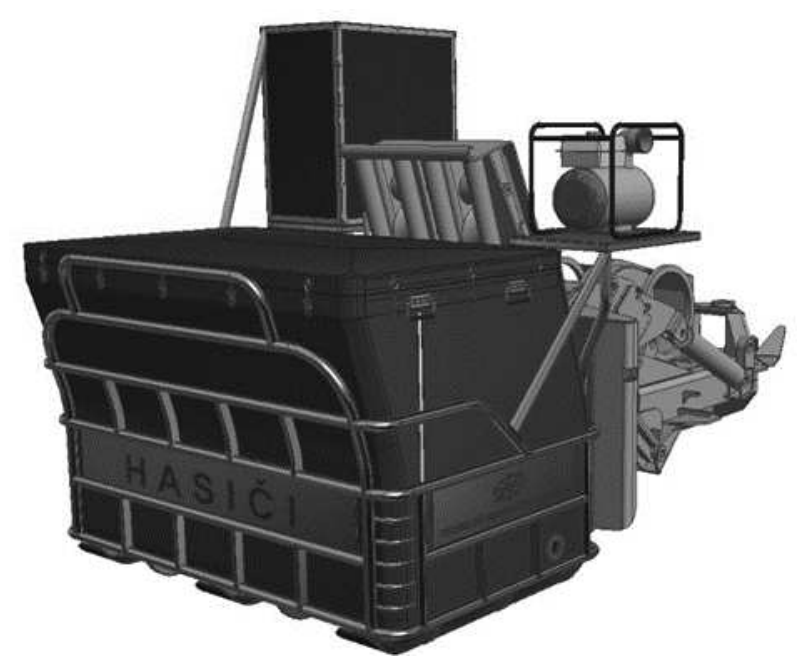

Fig. 3 Adapter frame with corner elements modification [4]

The frame of the fire adapter is made of structural steel. Some parts have been designed in a different design to achieve lightening of the adapter frame. Figure 3 shows the side part of the adapter frame where the welded sheet was replaced by bent steel tubes. Replacing steel elements with aluminium (in whole or in part) could contribute to weight lightening the entire adapter. The use of the aluminium alloy has been suggested for some parts to achieve lightening of the adapter frame. This includes the corner parts of the structure, the protective cover of the outlet valve etc. This doesn't apply directly to the supporting or connecting elements to the adapter structure itself. Possibilities of replacement of steel welded structures by aluminium requires mainly knowledge of mechanical and technological properties of aluminium replacement of which the weld ability is essential [5,7]. In general, for welds, it is first of all necessary to consider whether the stress is static or dynamic. The choice of allowable stresses for welds depends primarily on the type of stress, the mechanical properties of the base material, the weld design, the reliability with which the actual service load can be determined and the thoroughness of the weld inspection.
MIG welding (Metal Inert Gas) and TIG welding (Tungsten Inert Gas) are among the basic methods of fusion welding. MIG welding is a welding method in which an arc burns between the material to be welded and the metal electrode which is also the filler material. These welding methods and methods derived therefrom, which allow aluminium and steel to be welded without difficulty, are mainly used in transport engineering [6,8].

The welding of aluminium and its alloys has been known for several decades. Nevertheless, aluminium has some specific properties that cause considerable problems during welding. Aluminium has a low melting point (approx. $660^{\circ} \mathrm{C}$ ) and its colour does not change when it enters a liquid state. It has a very high thermal conductivity, which means that it needs a high concentration of energy for melting. Furthermore, it has a high affinity for oxygen and preferentially produces $\mathrm{Al}_{2} \mathrm{O}_{3}$. This oxide creates gases on the surface causing it to act as a thermal and electrical insulation barrier, which makes welding impossible. Aluminium oxide Al2O3 is hygroscopic, which means there is a risk of hydrogen pores. This is due to the different solubility of hydrogen on the molten and cold metal. Aluminium is also sensitive to $\mathrm{CO}_{2}$ when welding, which can also form pores even at low concentrations [9].

\section{Experiment}

The use of the aluminium alloy has been suggested for some parts to achieve lightening of the adapter frame. This includes the corner parts of the structure, the protective cover of the outlet valve etc. This doesn't apply directly to the supporting or connecting elements to the adapter structure itself.

Aluminium alloy AlSiMgMn (EN AW-6082) belongs to the 6000 -series - aluminium alloyed with magnesium and silicon. It is a medium resistant alloy with excellent corrosion resistance. It has the highest strength of all aluminium alloys in a 6000-series. 6082 alloy is known as a structural alloy, replacing 6061 alloy in many applications. It affects the grain structures by adding more manganese, resulting in an improvement in its properties. The chemical composition is given in Table 1 [10]. 
Tab. 1 Chemical composition of material AlSiMgMn EN AW-6082

\begin{tabular}{|c|c|c|c|c|c|c|c|c|}
\hline $\mathrm{Si}$ & $\mathrm{Mn}$ & $\mathrm{Mg}$ & $\mathrm{Fe}$ & $\mathrm{Cr}$ & $\mathrm{Zn}$ & $\mathrm{Ti}$ & $\mathrm{Cu}$ & $\mathrm{Al}$ \\
\hline $0.7-1.3$ & $0.4-1.0$ & $0.6-1.2$ & $<0.5$ & $<0.25$ & $<0.2$ & $<0.1$ & $<0.1$ & rest \\
\hline
\end{tabular}

In a 6000-series aluminium alloys, the amount of $\mathrm{MgSi}$ intermetallic phase is important for strength properties. Due to this, these alloys are heat treatable and have a certain analogy to the self-hardening steel, i.e. they are self-hardening. Their characteristic properties are excellent formability, weldability, corrosion resistance and machinability at medium strength properties. They are mainly used in transport components, bridge construction segments, architecture and in sports products, e.g. bicycle frames etc. Alloy AlSiMgMn has very good weldability in all welding methods (arc, resistance, in protective gas atmospheres). However, the strength in the weld area is reduced $[9,10]$.

Welding wire $\mathrm{AlMg} 5 \mathrm{Cr}$ (5356) is recommended as a filler weld material. In the cured state the tensile strength is $310 \mathrm{MPa}$. It was developed for welding aluminium alloys with a maximum magnesium content of $5 \%$. It has very good welding properties, excellent corrosion resistance and very good mechanical properties. In the cured state, the tensile strength is $\mathrm{Rm}=275-315 \mathrm{MPa}$, the yield strength is Rp0.2 $=115-140 \mathrm{~N} . \mathrm{mm}^{-2}$. The chemical composition of the filler material is shown in Table 2 . The weld metal is free of pores, but it is necessary to maintain perfect preparation of the welded surfaces. Thicker materials should be preheated to about $150^{\circ} \mathrm{C}$. Due to its properties, it is the most widely used wire in the aluminium alloy category. It is mainly used in shipbuilding, in rail transport etc. $[9,10]$.

Tab. 2 Chemical composition of material AlMg5Cr

\begin{tabular}{|c|c|c|c|c|c|c|c|c|}
\hline $\mathrm{Mg}$ & $\mathrm{Mn}$ & $\mathrm{Cr}$ & $\mathrm{Fe}$ & $\mathrm{Si}$ & $\mathrm{Cu}$ & $\mathrm{Zn}$ & $\mathrm{Ti}$ & $\mathrm{Al}$ \\
\hline $5.0-5.5$ & $0.6-1.0$ & $0.05-0.2$ & $<0.4$ & $<0.25$ & $<0.1$ & $<0.2$ & $0.05-0.5$ & rest \\
\hline
\end{tabular}

Based on the WPS, aluminium sheets were welded for the experiment. Their correct choice should guarantee a high-quality weld joint, which should replace the welding of heavier, steel parts. The specification of welding parameters is given in Table 3. All relevant parameters were consulted by experts with extensive experience in the field of welding aluminium alloy.

Tab. 3 Specification of welding parameters

\begin{tabular}{|c|c|c|c|}
\hline \multicolumn{2}{|c|}{ Parameter } & Value/Marking & Welds diagrams \\
\hline \multicolumn{2}{|c|}{ Sheet thickness AlSiMgMn } & $\mathrm{t}_{1,2}=5.0 \mathrm{~mm}$ & $\Rightarrow \quad t 2$ \\
\hline \multicolumn{2}{|c|}{ Welding groove } & $\mathrm{c}=0-0.5 \mathrm{~mm}$ & \\
\hline \multicolumn{2}{|c|}{ Weld type } & kútový zvar - FW & \\
\hline \multicolumn{2}{|c|}{ Weld throat } & a4 & \\
\hline \multicolumn{2}{|c|}{ Weld position } & $\mathrm{PB}$ & 0 \\
\hline \multicolumn{2}{|c|}{ Joint thickness range } & $5.5 \mathrm{~mm}$ & 4 \\
\hline \multicolumn{2}{|c|}{ Type of welding process } & MIG - 131 & $+\Delta 11111117$ \\
\hline \multicolumn{2}{|c|}{ Filler material - solid wire } & EN ISO 18273-S Al 5356 AlMg5Cr & \\
\hline \multicolumn{2}{|c|}{ Diameter of the welding wire } & $1.2 \mathrm{~mm}$ & \\
\hline \multicolumn{2}{|c|}{ Number of layers } & 1 & \\
\hline \multicolumn{2}{|c|}{ Wire feed speed } & $10.4 \mathrm{~m} \cdot \mathrm{min}^{-1}$ & \\
\hline \multicolumn{2}{|c|}{ Welding speed } & $461-489$ m.min ${ }^{-1}$ & \\
\hline \multirow{3}{*}{ Current } & Base & $163-165 \mathrm{~A}$ & \\
\hline & Impulse & $130-135 \mathrm{~A}$ & \\
\hline & $\begin{array}{l}\text { Fre- } \\
\text { quency }\end{array}$ & $176 \mathrm{~Hz}$ & \\
\hline \multicolumn{2}{|l|}{ Voltage } & $23.6-23.8 \mathrm{~V}$ & \\
\hline \multicolumn{2}{|c|}{ Type of voltage/polarity } & $=/+$ & \\
\hline \multicolumn{2}{|c|}{ Welding energy } & $0.25-0.30 \mathrm{~kJ} . \mathrm{mm}^{-1}$ & \\
\hline \multicolumn{2}{|c|}{ Shielding gas (EN ISO 14175) } & $\mathrm{I1}-\mathrm{Ar}$ & \\
\hline \multicolumn{2}{|c|}{ Gas flow } & $151 . \mathrm{min}^{-1}$ & \\
\hline \multicolumn{2}{|c|}{ Welder qualification } & STN EN ISO 9606-2 & \\
\hline
\end{tabular}

The following methods were used to assess weld quality:

-macroscopic analysis,

-measurement of hardness - the Vickers method,

-microscopic analysis - SEM with EDX analyses

\section{Results and discussion}

A macroscopic analysis was performed to assess the quality of the welded joints (Figure 4). We can state that the weld joint in Figure $4 \mathrm{a}$ is of higher quality than weld joint in Figure 4b. The figure shows the cavity at the root of the weld. 

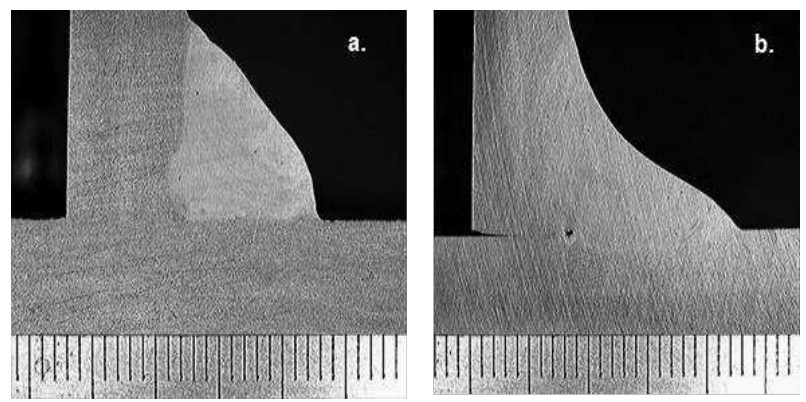

Fig. 4 Macroscopic analysis of welded joints
Sample preparation was performed in a standard manner. It consisted of sampling of a suitable size for embedding in the resin. Metallographic preparation consisted of embedding, grinding of sample (grain size 800, 1200 and 2000) and polishing with diamond emulsions with gran size $3 \mu \mathrm{m}$ and $1 \mu \mathrm{m}$. Etchant $\mathrm{NaOH} 1 \%$ was used for etching to induce structure.

Furthermore, Vickers hardness test was made [11,12]. The measurement was performed on a sample shown in Figure 5a. Figure 5b shows a graph of hardness progress from the base material through the weld and back to the base material.
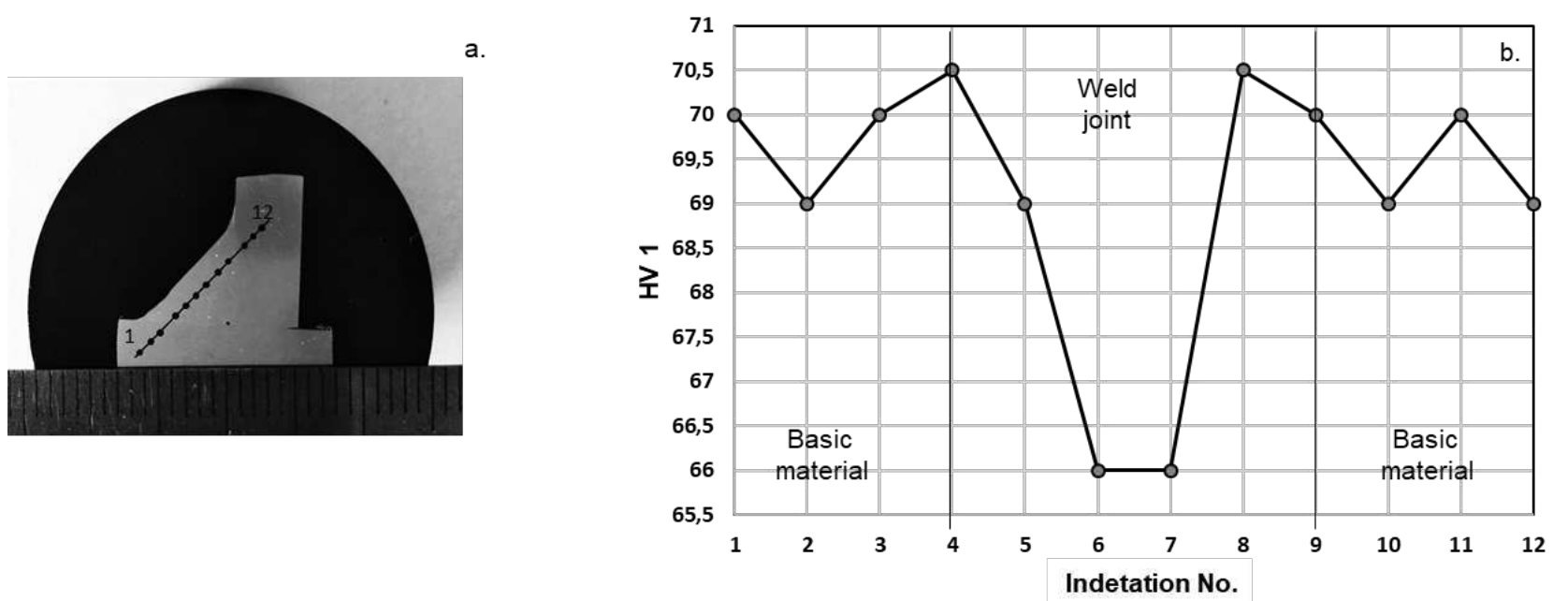

Fig. 5 HV1 measurement on sample (a.); recording of hardness in weld joint (b.)

Evaluation of weld joint was performed by electron microscopy to evaluate and control the base material AlSiMgMn EN AW-6082 (Figure 6a) as well as the filler
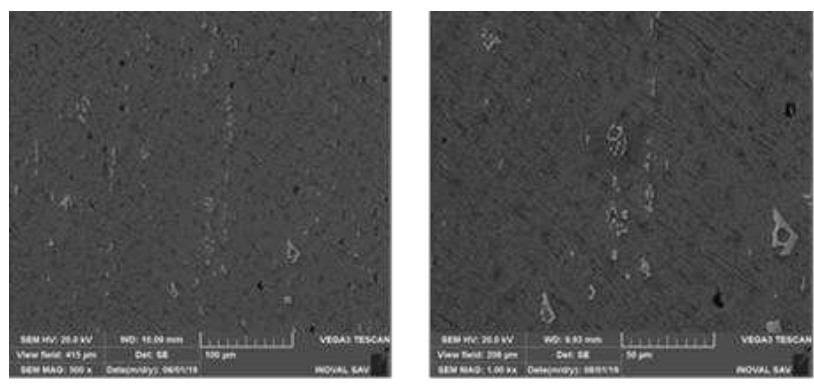
a.

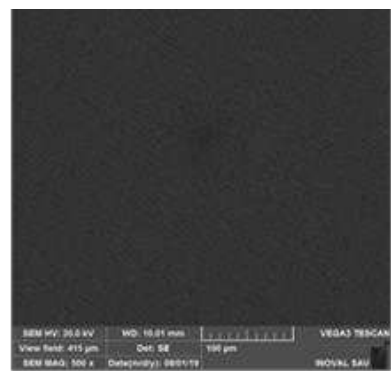
material AlMg5Cr (5356) (Figure 6b).

Fig. 6 Images of base material (a.) and weld filler material (b.)

Fig. 7 shows the quality of mixing the base material with the filler material. The figure also shows a detail of
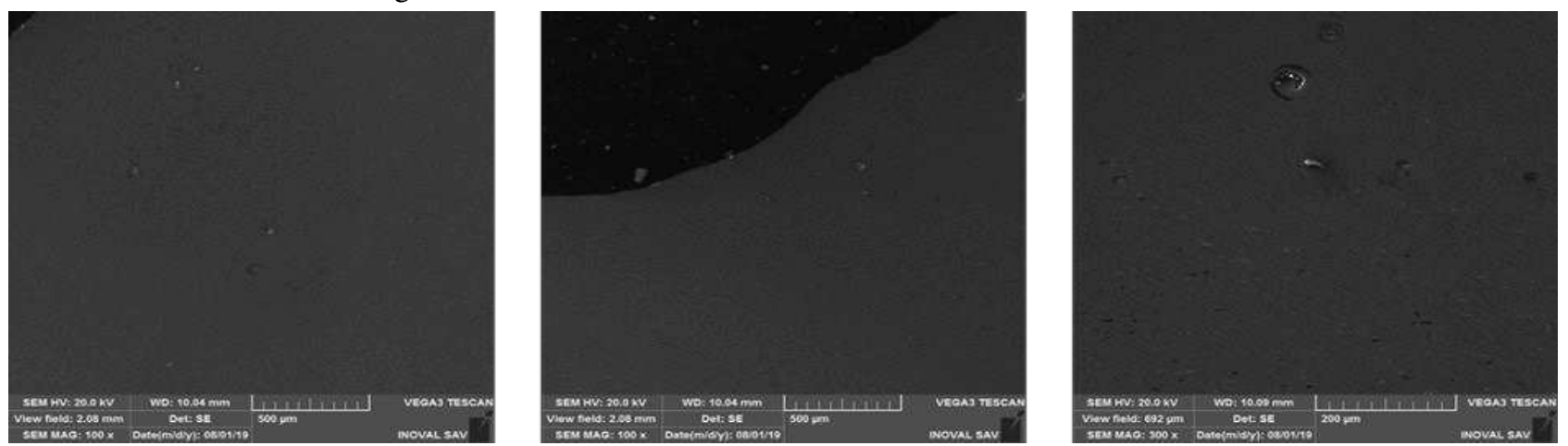

Fig. 7 Weld joint interface details

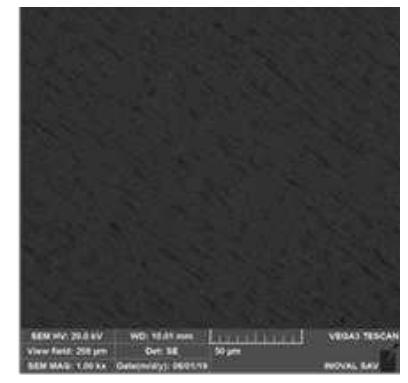
b. the weld joint interface. 
Fig. 8 shows SEM images of the base material. The observed values correspond to the values given in the alloy data sheet AlSiMgMn EN AW-6082 (Table 4).

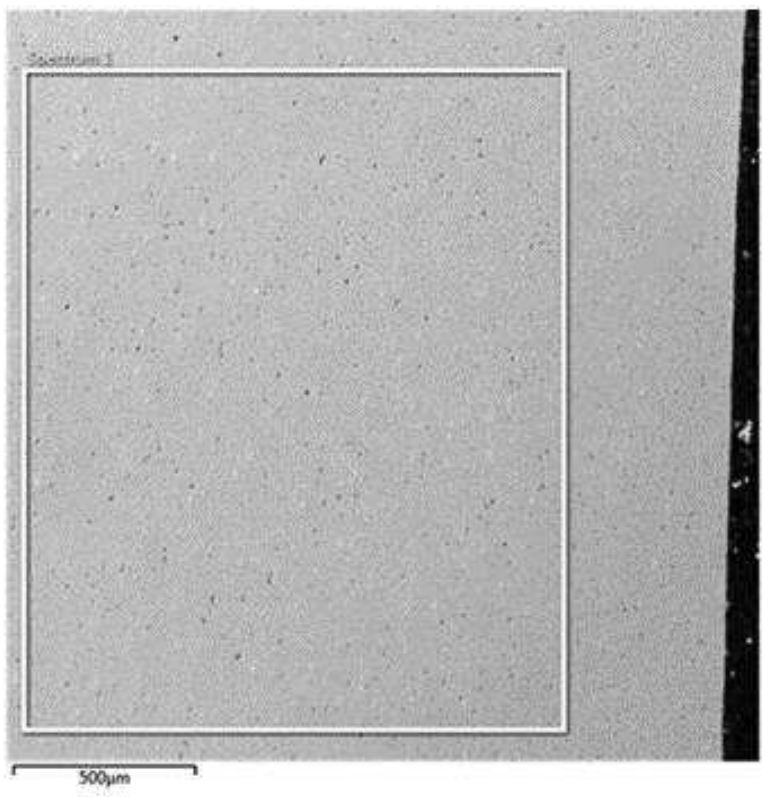

Fig. 8 SEM analysis of basic material

Tab. 4 Values of chamical elements of spectre 1

\begin{tabular}{|c|c|c|c|c|c|}
\hline $\begin{array}{c}\text { Statistic } \\
\text { of Spectrum 1 } \\
\text { [weight \%] }\end{array}$ & $\mathrm{O}$ & $\mathrm{Mg}$ & $\mathrm{Al}$ & $\mathrm{Si}$ & $\mathrm{Mn}$ \\
\hline Max & 1.66 & 0.64 & 96.19 & 1.04 & 0.46 \\
\hline Min & 1.66 & 0.64 & 96.19 & 1.04 & 0.46 \\
\hline Average & 1.66 & 0.64 & 96.19 & 1.04 & 0.46 \\
\hline Standard Deviation & 0.00 & 0.00 & 0.00 & 0.00 & 0.00 \\
\hline
\end{tabular}

SEM image of the weld joint is shown in Fig. 9. The magnesium value was mostly captured at a level corresponding to the chemical content of the weld material according to the data sheet of the filler material $\mathrm{AlMg} 5 \mathrm{Cr}$ (Table 5).

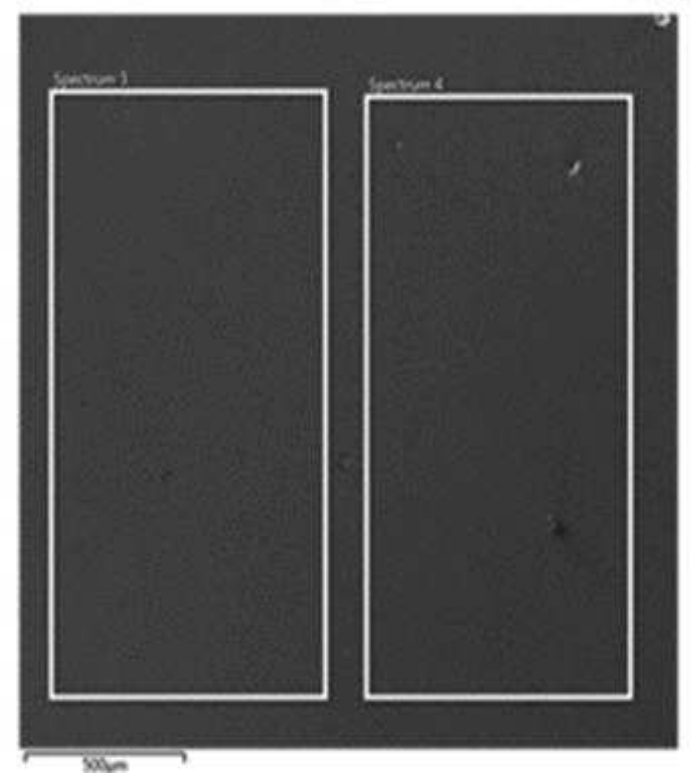

Fig. 9 SEM analysis of welded joint
Tab. 5 Values of chamical elements of spectres 3 and 4

\begin{tabular}{|c|c|c|c|}
\hline $\begin{array}{c}\text { Statistic [weight \%] of } \\
\text { Spectres 3 and 4 }\end{array}$ & $\mathrm{O}$ & $\mathrm{Mg}$ & $\mathrm{Al}$ \\
\hline Max & 1.15 & 4.19 & 94.83 \\
\hline Min & 0.98 & 4.15 & 94.70 \\
\hline Average & 1.07 & 4.17 & 94.76 \\
\hline Standard Deviation & 0.12 & 0.03 & 0.09 \\
\hline
\end{tabular}

Fig. 10 shows SEM images in the transition area. A larger spectrum of chemical elements was captured on the analysis area by mixing the base material and the filler material (Table 6).

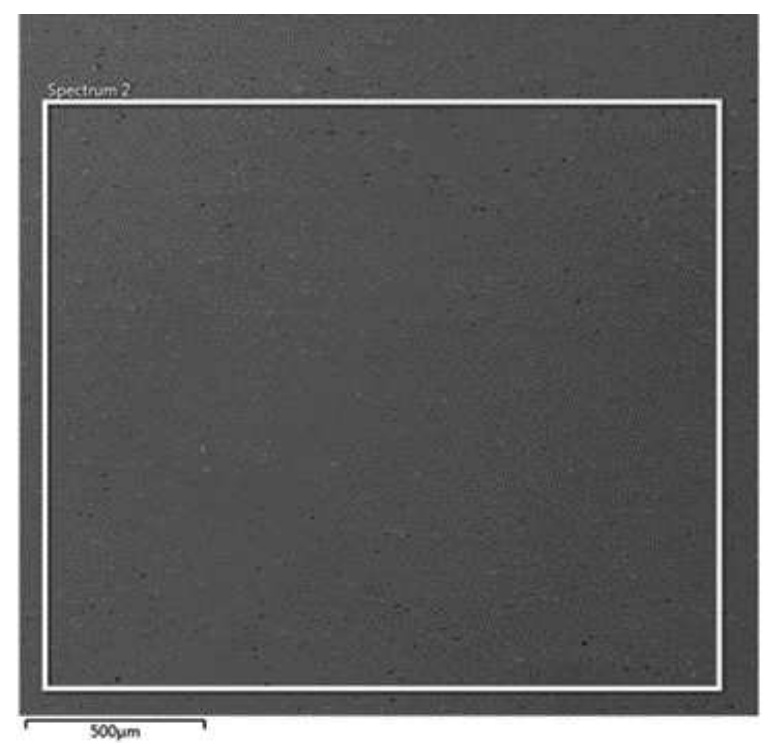

Fig. 10 SEM transition area results

Tab. 6 Values of chamical elements of spectrum 2

\begin{tabular}{|c|c|c|c|c|c|}
\hline $\begin{array}{c}\text { Statistic } \\
\text { of Spectrum 2 } \\
\text { [weight \%] }\end{array}$ & $\mathrm{O}$ & $\mathrm{Mg}$ & $\mathrm{Al}$ & $\mathrm{Si}$ & $\mathrm{Mn}$ \\
\hline Max & 1.45 & 0.62 & 96.56 & 0.97 & 0.40 \\
\hline Min & 1.45 & 0.62 & 96.56 & 0.97 & 0.40 \\
\hline Average & 1.45 & 0.62 & 96.56 & 0.97 & 0.40 \\
\hline Standard Deviation & 0.00 & 0.00 & 0.00 & 0.00 & 0.00 \\
\hline
\end{tabular}

The weld joints of the aluminium alloy AlSiMgMn EN AW-6082 were evaluated using macroscopic analysis, measurement of hardness by HV1 and microscopic analysis associated with EDX analysis. Using SEM, it is possible to analyse in detail the disturbances, errors or deformations on the worn surface with greater magnification as possible by light microscopy $[13,14]$. The wire $\mathrm{AlMg} 5 \mathrm{Cr}$ was selected as the filler material. Attention was paid to the selection of welding parameters by the MIG method during the development of WPS. Correctly set parameters of the welding equipment guarantee a quality joint [9]. Using the proposed methods for evaluating welds, we examined whether the welds had sufficient mixing of the base and filler material without visible defects such as cracks, seams or cold joints. Although the proposed welds are not directly bearing welds, the STN EN ISO 6520:2008 [15] states that cracking is not acceptable in any case. Values from the base material as well as from the weld joint were obtained by evaluation of hardness by 
HV1 measuring method. The graph (Fig. 5b) shows that there was a decrease in hardness of about 5 Vickers units in the weld. On the other hand, the highest hardness (70HV1) is in the transition zone. Base on the results, we can conclude that the weld joint should be strong enough to withstand the load it is exposed to in operation.

It can be stated that the welds produced meet the basic requirements for this type of welds. The welding parameters were appropriately selected. After further testing and experiments, the proposed weld joints can be used in adapter frame construction.

\section{Conclusion}

The article deals with the possibility of reducing the weight of adapters used in forest technic which is necessary for several reasons. For economic reasons - mainly to reduce the energy intensity of equipment and also environmentally because of the burden on the soils of all work activities in forestry. By using lighter constructions such as replacing steel aluminium elements in their designs, we can contribute to reducing this adverse effect.

\section{Acknowledgments}

The article was supported by the APVV-16-0194 "Research on Impact of Innovation in Production Processes on the Life of Tooling and Components of Forest Mechanisms."

This work was supported by the Slovak Research and Development Agency under the contract No. APVV-140468 „Development of an auxiliary device and its technological employment to increase the efficiency of extinguishing forest fires."

\section{References}

[1] SCHWARZ M. et al. (2013). Environmentálne problémy $v$ priemysle a t’ažbe, pp. 337. 1. ed., Technická univerzita vo Zvolene, Zvolen.

[2] HNILICA R. et al. (2015). Možnosti mechanizácie prác pri zakladaní a výchove lesa. pp. 99. Technická univerzita vo Zvolene, Zvolen.

[3] WIESIK J., ANISZEWSKA M. (2011). Technical Equipment in forest production, Volume 1 Equipment for forest breeding and protection, pp. 237240. SGGW Publisher, Warszawa.

[4] HNILICOVÁ M. et al. (2018). Analýza využitia lesného kolesového t'ahača $\mathrm{k}$ doprave vody na miesto lesného požiaru, In: Aktuálne otázky v ochrane lesov pred požiarmi (R. Hnilica, I. Chromek, Ed.)), pp. 26-33. Technická univerzita vo Zvolene, Zvolen.
[5] MATEJ J., HNILICOVÁ M., HNILICA R. (2018). Modifikácia nosnej konštrukcie hasičskej nadstavby. In: Aktuálne otázky v ochrane lesov pred požiarmi (R. Hnilica, I. Chromek, Ed.)), pp. 58-64. Technická univerzita vo Zvolene, Zvolen.

[6] MICHNA Š. et al. (2005). Encyklopedie hliníku, pp. 131. Adin, s. r. o., Prešov.

[7] MORAVEC J., NOVÁKOVÁ, I., BRADÁČ, J. (2016). Effect of Age Hardening Conditions on Mechanical Properties of AW 6082 Alloy Welds. In: Manufacturing Technology, Vol. 16, No.1, pp. 192-198. FSI UJEP, Ústí nad Labem. Czech Republic.

[8] PATEK, M. MIČIAN, M., SLÁDEK, A. KADÁŠ, D. (2016). Numerical Analysis of T-Joint Welding with Different Welding Sequences. In: Manufacturing Technology, Vol. 16, No.1, pp. 234-238. FSI UJEP, Ústí nad Labem. Czech Republic.

[9] GRUNDMANN J. (2019). Zváranie MIG hliníka a jeho zliatin [online]. [cit. 17.07.2019]. Available on https://www.engineering.sk/clanky2/zvaranie/197-zvaraniemighlinikaajehozliatin.

[10] NPS PROAL s.r.o. Hliník [online]. [cit. 17.07.2019]. Available on https://proal.cz/hlinik/slitiny-hliniku/en-aw-6082/

[11] STN EN ISO 6507-1:2006 Kovové materiály: Vickersova skúška tvrdosti. Čast' 1., Skúšobná metóda. SÚTN Bratislava.

[12] STN EN ISO 6507-4:2006 Kovové materiály: Vickersova skúška tvrdosti. Čast' 4., Tabul'ky hodnôt tvrdostí. SÚTN Bratislava.

[13] NÁPRSTKOVÁ, N., CAIS, J., STANČEKOVÁ, D., KRAUS, P. (2016). Analysis of the composition of selected interts using electron microscopy. In: Manufacturing Technology, Vol. 16, No. 5, pp. 1063-1067. FSI UJEP, Ústí nad Labem. Czech Republic.

[14] SVOBODOVA, J. (2014). SEM and EDS Analysis Used in Evaluation of Chemical Pre-treatment Based on Nanotechnology. In: Manufacturing Technology, Vol. 14, No. 3, pp. 461-467. FSI UJEP, Ústí nad Labem. Czech Republic.

[15] STN EN ISO 6520:2008 Zváranie a príbuzné procesy. Zatriedenie chýb zvarových spojov kovových materiálov. Čast' 1: Tavné zváranie. SÚTN Bratislava. 